\title{
Cardinals, Inquisitors, and Jesuits: Curial Patronage and Counter-Reformation in Cosimo I's Florence
}

GREGORY MURRY

Cet article analyse les motivations $d u d u c$ de Florence Côme I qui l'ont amené à soutenir l'inquisition et les activités des jésuites entre 1540 et 1560. À travers l'examen de la correspondance gouvernementale et des archives concernant les bénéfices Toscan, cette étude met en lumière les liens entre le mécénat de la curie et les instances de la réforme Catholique, sous trois aspects interreliés. Premièrement, Côme n'a pas rompu ses liens spirituels avec Rome, puisque cela aurait mis en danger les intérêts séculiers de son réseau de clients, qui ceux-ci avaient une grande activité au sein des États Papaux. Deuxièmement, étant donné cette restriction, le duc a dû établir des liens avec des cardinaux de la curie pouvant lui garantir des faveurs séculières et spirituelles pour son réseau de clients. Troisièmement, par la suite, ces mêmes cardinaux ont profité de leur position stratégique pour renverser le rapport de force et ainsi imposer l'inquisition et les Jésuites au gouvernement florentin réticent.

$\mathrm{W}$

ith its large, literate middle class and burgeoning capitalist economy, Florence should have been a city ripe for reformation. Indeed, if sociological considerations alone mattered, Cosimo I's nasty personal relationship with Pope Paul III would have exploded into outright revolt, and the networks of heretical opinion circulating among the city's cultured elite would have found fertile ground on Tuscan soil. ${ }^{1}$ However, sociology seems ill-suited to explain why Italy stayed Catholic since Italy had its cities, artisans, merchants, and nascent capitalism long before England, France, or Germany. It even had its own considerably lively strains of heterodoxy. ${ }^{2}$ Yet, all these produced nothing comparable to the Puritan, Huguenot, or Lutheran movements. Most Italian heresies were scotched in the cradle before they could spread; the apparatus of inquisitorial repression and Jesuit education made sure of that. Thus, scholars of the Italian reformation have rightly chosen to give pride of place to the relations between political power and the agencies of Catholic reform. ${ }^{3}$ And this makes sense. In the mid sixteenth-century, Italian governments 
showed considerably more deference to inquisitorial and Jesuit projects than their transalpine brethren.

But why? Why did the agencies of Catholic reform find such knee-buckling pliability among rulers like the Florentine Duke Cosimo I? Old explanations have their merit, but they have their difficulties as well. For instance, the subject's most authoritative historian claimed that Cosimo I got on board with reform because he thought supporting Roman primacy was the only way to salvage Italian political power. ${ }^{4}$ However, Cosimo was not particularly interested in Italian political power per se; he was interested in his own state, and he would have slit his neighbours' throats to safeguard it. Another explanation suggests that Cosimo thought a revolution in religion would herald a revolution in government, but this does not seem to explain the situation fully either. ${ }^{5}$ By the time of Cosimo's first auto-da-fé, there were a number of real-life counter examples to the argument, examples of which the politically savvy duke would have been well aware. Thus, this essay points to another dynamic, arguing for three interrelated points. First, despite considerable tensions with Pope Paul III, Cosimo could not have broken spiritual ties with Rome without jeopardizing the secular interests of his client network, a network that conducted considerable activity in the Papal States. Thus, when it came to ecclesiastical policy, Cosimo's patronage ties prevented him from becoming either a reformation prince or an absolutist prince. Second, given his inability to cut ties, the duke needed to find cardinals in the curia who could guarantee secular and spiritual favours for his client network. Third, this patronage network eventually boomeranged back on him, as his cardinal protectors used their strategically won position to foist both the inquisition and the Jesuits on a reluctant Florentine government. In short, this essay makes the case for a distinctive link between curial patronage and the success of the Counter-Reformation in Florence.

\section{Florence and the Roman Connection}

Few rulers ever had better reasons to dislike a pope than did Cosimo. Bad feeling between the duke and Pope Paul III abounded almost immediately, for in Cosimo's first year, Paul snatched away the widow of the duke's assassinated predecessor for his own grandson Ottaviano, robbing the new prince of his hope of bringing her to his own marriage bed. ${ }^{6}$ Paul then proceeded to derogate the patronage rights on some of Tuscany's choicest benefices by wielding the powers of excommunication, and to extort a tithe out of an impoverished Tuscan clergy by unsheathing the spiritual sword of interdiction. Cosimo rightly assumed that Paul wanted Florence for his 
own and was rightly afraid that the tithe money his priests sent out might return in the pockets of the pope's mercenaries. Short years later, duke and pope almost came to blows over Cosimo's expulsion of the Dominican Savonarolans of San Marco. Cosimo ostensibly expelled them for reasons of state, but the Dominicans found a sympathetic ear in the papal chair, and Paul rushed to their defence. The pope staked his protection of the Savonarolans primarily on jurisdictional grounds, but the irony of a pope protecting the spiritual children of a disobedient heretic did not go unnoticed by the baffled duke. ${ }^{7}$

Despite all that, Cosimo's options in confronting Rome were limited, and he had little choice but to play the hand he was dealt. It was Rome's game, and he played it on Rome's terms. Indeed, Rome was no ordinary neighbour. With a strange shape, jutting aggressively northwards around the eastern edge of Tuscany, the Papal States formed an uncomfortably high percentage of his border. Moreover, because the same set of Roman hands dispensed both spiritual and temporal favours, a working relationship with the papal curia was indispensable. Most importantly, the considerable back and forth of peoples, moneys, and offices between the neighbours dictated that Cosimo develop contacts who could protect his clients' interests in Rome. Cutting spiritual ties, or "going Turk" as Cosimo put it, ${ }^{8}$ would simply have put his secular interests in the Papal States in too much jeopardy. Moreover, winning the loyalties of his subjects by getting them favours in Rome was a sine qua non of holding the first position in Tuscany.

What stoked the voracious Tuscan appetite for favours in the papal curia? For starters, Tuscans conducted more than their fare share of civil and financial business with their southern neighbour, often invading the Tiber's banks as foreign bankers and merchants. In litigious early modern Italy, legal issues always nipped hot on the heels of business ventures, and with not infrequent regularity Tuscans found themselves standing before Roman tribunals. The whole process could be quite daunting because, unsurprisingly, the ability to get anything accomplished in Roman courts was indissolubly linked to whom one knew, what strings one could pull, and what favours one could call in. As one of Cosimo's supplicants complained, his case had been dragged out for "four months without being able to end it, because of the many favors given to the adversary, a familiar of Reverend Cardinal Trani."9 A good number of such unhappy litigants had little clue how to navigate the snaking turns of curial politics. Faced with such bleak prospects, they often turned to the most powerful patron they knew: Cosimo. Cosimo was happy to oblige, putting his clients directly in his debt with little more than the dispatch of a letter. Legion are the occasions on which Cosimo called on his patronage network in Rome to 
expedite a case or provide legal favours. ${ }^{10}$ If Tuscany was to continue doing business with Rome, they simply could not avoid legal entailments in the Papal States, and they could not prosecute them successfully without a patron. Cosimo had to step into the breach.

Legal favours made up a large part of Cosimo's patronage business, but there were other favours to be had in Rome. For instance, Tuscans who could not find opportunities to ply their trades in a Tuscan post often looked to the Church's state. For physicians, lawyers, philosophers, and humanists, curial Rome was a welcome alternative to the duke's notoriously tight-fisted government. However, like legal favours, choice jobs were usually not to be had without connections. So, when Tuscans went to Rome, they armed themselves with a credential letter from their duke and patron. As a result, Tuscans' ability to make their way in the Papal States very often depended on what mood the curia had toward Cosimo at any given moment. ${ }^{11}$

This flow of peoples was no one-way street; convivial Florence siphoned its fair share of the Pope's citizens in its turn. Cosimo encouraged this, enticing such adventurers as Ridolpho Baglioni, Stefano Palestina, Stefano Colonna, Giovan Batista Savelli, and Conte GiovanFrancesco da Bagno into his employ as soldiers of fortune. ${ }^{12}$ Ties of blood linked Cosimo to other subjects of the Papal States. For instance, Cosimo numbered the Rossi of San Secondo and the Cybo's of Massa-Carrara among his kinsmen. ${ }^{13}$ Thus, Cosimo's clients and family kept him entangled in papal politics whether he willed it or not. For instance, in 1549 Cosimo's Colonna clients goaded him into asking Julius III to restore them to a castle they had held under Clement VII. ${ }^{14}$ When short years later, Cosimo found himself Stefano Colonna's heir, he called on one of his cardinal intercessors to protect the widow. ${ }^{15}$ When Lorenzo Cybo's wife died in 1553, Cosimo wrote on his relatives' behalf to the Cardinal Legate of Perugia, trying to keep the papal contado of Ferentillo under the family's control. ${ }^{16}$ Cosimo intrigued to keep the Rossi in their feud of San Secondo during the Farnese wars over Parma, ${ }^{17}$ and the loyal duke got the displaced Perugian rebel Ridolpho Baglioni restored to a new state in papal territory under the auspices of Julius III's good graces. ${ }^{18}$ When Cosimo again got a friendly pope in Pius IV, he tried to use his influence to get Conte GiovanFrancesco da Bagno safe passage to defend his rights in the deprivation of his state. ${ }^{19}$ Thus, friendly contacts in Rome were essential if Cosimo was to protect the interests of clients holding land or titles from the pope.

Cosimo's client network was not only swamped with high ranking papal feudatories, but also with men of more modest lights, who got themselves in serious 
trouble in the papal patrimony with astonishing regularity. Petty vendettas escalated into homicide with such frequency that the history of the age reads as much like an Icelandic saga as the rebirth of Western Civilization. When the desperate end of murder was consummated, the offenders often came scampering across the Tuscan border to the safety of foreign lands. Extradition was a dodgy proposition and pursued only for certain types of criminal. Those exiled guests who could win Cosimo's favour and patronage found that they had won a powerful ally in getting the sentence remitted in the pope's courts. For instance, Cosimo was inclined to help Bernardo Camaiani, brother of two of his closest confidants, to make peace with the family of his victim and to gain pardon from the pope. ${ }^{20} \mathrm{Cosimo}$ was also inclined to offer his protection to men like Antonio Barzellino, a Medici client who had killed his wife in a fit of passion when he found her committing adultery. Those were just the kind of extenuating circumstances that Cosimo thought deserved a little clemency, and his Barzellino client was just the type of man whom Cosimo was of a mind to help. ${ }^{21}$

Thus, secular matters snared Cosimo into a Roman net from which he could not have disentangled himself even if he had so chosen. Rome's dominion over the world of the spirit only doubled its importance. Matrimonial cases, inheritance cases, benefice cases: Rome claimed the right to adjudicate over a broad swath of life. If a priest or bishop wanted to renounce a benefice, he often had to go to the Roman courts. ${ }^{22}$ More importantly, all dispensations needed to be run through the papal datary. Any priest who found that he did not possess the right qualifications for holding a benefice had to throw himself on the mercy of the curia. ${ }^{23}$ Too young, too old, too criminal, too married: any number of reasons might drive a priest to ask for Cosimo's assistance. To exacerbate the issue, the ordinary hierarchy was not the only hierarchy out of Cosimo's control; intervening with the regular orders normally required the use of the Roman connections as well. ${ }^{24}$ Any number of modest requests came before Cosimo, and he would have been expected to help the second estate with the same alacrity that he helped his other subjects.

There is little surprise that aspiring clerics came cap-in-hand to beg Cosimo's assistance, but Cosimo's game was bigger than that. In pursuit of wider influence over the Tuscan church, he put his network at the convenience of his own bishops, who had as much business to conduct in the Roman courts as anyone. When they wanted to renounce their bishopric, they needed a dispensation, which occasioned Cosimo's intercession. ${ }^{25}$ When they wanted to reform a monastery or punish some troublesome monks, they needed the cooperation of the regular hierarchy, which meant getting Cosimo to unleash his cardinal protectors on the generals of various 
orders. ${ }^{26}$ When they were having a dispute over some pensioned benefice, they needed a legal favour, and Cosimo was the man for that. ${ }^{27}$ Even when they wanted a promotion, they came to him. Not only did he help secure some of his clients a red hat, ${ }^{28}$ he even helped two of them to the biggest promotion of all, playing the role of pope-maker in the conclaves that elected Julius III and Pius IV. ${ }^{29}$ Indeed, since so many beat a path to his door asking for favours, he simply could not ignore the Roman network.

\section{Winning Friends and Influencing Cardinals: Networks of Ecclesiastical Patronage}

How did Cosimo so quickly achieve such influential patron status? Simply by using time tested patterns of patronage networking: family ties, ties of mutual interest, and ties to neighbouring power brokers. Having mastered this art quickly, Cosimo built up a very impressive network of cardinal patrons in a very short amount of time, winning over the cardinals Santa Fiora, Savello, Santiquattro, and even his uncle Salviati, a one-time enemy who swallowed hard and reconciled with Cosimo in order to wriggle his way into the emperor's good graces. However, three early contacts emerged as critical links to Rome: Juan Alvarez de Toledo, the Bishop of Burgos and later Compostella; Giovanni Maria Ciocchi del Monte, better known as Pope Julius III; and Ridolfo Pio di Carpi, the one time bishop of neighbouring Faenza.

Cosimo did his most important patronage networking the old fashioned way: he married into it. And while he may have chosen Eleanora de Toledo for love, eschewing the Viceroy of Naples' notoriously ugly and awkward older daughter for the stately elegance of the younger sister, the alliance with the family was itself rather coldly calculated. That move not only won him powerful friends in the court of Charles I, it won him one very powerful voice in Rome: the influential Toledo cardinal. As the son of the second Duke of Alba, Toledo was brother to the Viceroy of Naples and uncle to the duke's new bride. Moreover, he was no mere leftover from the Medici days as popes; Paul himself had given him the red hat in 1538, and Toledo had real influence in Rome..$^{3 \circ}$ Cosimo did not waste time in putting his new familial connections to work, leaning on Toledo as a crutch in the curia during the $1540 \mathrm{os}$ and $1550 \mathrm{os}$. Whether it concerned the most important matters of Roman patronage, like attempting to get his son made Archbishop of Pisa, ${ }^{31}$ or the least important matters, like trying to win an inheritance case for a poor client widow, ${ }^{32}$ archival evidence suggests that Cardinal Toledo was Cosimo's primary go-to. ${ }^{33}$ 
Moreover, Toledo was not only a useful ally in Rome but in Florence as well because Cosimo's subjects constantly harassed him for benefices that the duke could not deliver. Frustrated with one such request, Cosimo apparently threw up his hands and referred the matter to his Toledo protectors with the exasperated quip, "I do not know who better can make graces of benefices than Cardinal Burgos or Don Francesco Toledo because I am the duke, and the duke does not give benefices or ecclesiastical revenues." ${ }^{4}$ We see here how far Cosimo was from an absolutist in ecclesiastical affairs, as he needed to lean on his Spanish relatives even to satisfy his own subjects' appetites for ecclesiastical goods.

Both of Cosimo's other two Cardinal contacts were neighbours, allowing our prince to win them over with that other great leg of patronage networking: mutual interest, for no one could seize benefices in Tuscany without the ducal placet. ${ }^{35} \mathrm{As}$ one time legate to the Marche and one time bishop of Faenza, ${ }^{36}$ Cardinal Carpi had considerable interest on Tuscan soil. My research affirms that he asked for Cosimo's assistance in securing at least three Tuscan benefices for his own clients, but the number is likely greater than that. ${ }^{37}$ In one case, Cosimo had to ride to Carpi's rescue and battle off a rival claimant who was trying to seize the benefice by force of arms. ${ }^{38}$ In his turn, Cosimo called on the neighbouring cardinal on a number of important occasions. When he wanted to reform the conventual Franciscans, he enlisted the help of Carpi, who was the protector of the order. ${ }^{39}$ When he wanted to secure the generalship of the still troublesome friars for his own confidant, he tried to get Carpi to fix the election. ${ }^{40}$ And when he was trying to get one of his own secretary's inquisitorial cases expedited, he penned Carpi an impassioned plea. ${ }^{41}$ Of course, these were only the tip of the iceberg. Routine smaller favours begged from Carpi filled up volumes of correspondence as well. ${ }^{42}$ In these, Carpi was one of Cosimo's most consistent friends, and their friendship lasted until the prelate succumbed to his gout in 1564 .

Carpi was a small gamble. Like Cosimo, he was an imperialist, so Cosimo risked little in courting his patronage. The gamble that really paid dividends was the relationship Cosimo cultivated with Cardinal Del Monte, who had sought the duke's goodwill as early as $1542 .{ }^{43}$ Del Monte had good reason to do so since Paul III soon granted him all of the benefices that had belonged to the cardinal's deceased uncle, many of them in their native Monte San Sovino, in the diocese of Arezzo. Cosimo's archives show that Del Monte's attempts to turn grace into revenue quickly degenerated into a mess of competing claims and threats. Thus, Cosimo's friendship was fundamentally important for Del Monte, and Cosimo did all he could for him, readily giving the agent immediate possession of any non-disputed 
benefices, ${ }^{44}$ agreeing to the possession on those benefices for which he personally held the ius patronato, 45 and even using the bully stick to force others to cede their claims to the del Montes. ${ }^{46}$ In 1546 , Cosimo did Del Monte an even bigger favour, reserving all cases involving the cardinal's benefices personally to himself, to be heard only by his auditor, Lelio Torelli. ${ }^{47}$ Cosimo's gamble did not go unrewarded. Del Monte was Cosimo's lifeline at the first session of the Council of Trent, and their relationship was solidified by the lifelong friendship that Del Monte cultivated there with Cosimo's ambassador. ${ }^{48}$ It comes as no surprise then that Del Monte backed Cosimo at the papal court in his precedence controversy with the Duke of Ferrara. ${ }^{49}$ Cosimo returned the favour; against the inclination of the emperor, the aspirant king maker pushed Del Monte through as a compromise candidate in the 1549 conclave. ${ }^{50}$ This was an undoubted triumph. Cosimo had long suffered under the ire of an unsympathetic pope, and a candidate that owed the election primarily to him was a welcome change.

In the twelve short years between his ascension to the ducal throne and Del Monte's ascension to the papal chair, Cosimo had come a long way. In 1537, even his own cardinal uncle had tried to get rid of him, an outcome that would have delighted the pope even though he refused to lift a finger to make it happen. By 1549 that uncle had been put in his place, and even Paul III had made his peace with Cosimo. Indeed, attitudes toward the young duke had palpably changed, and the tentacles of his petty empire of patronage extended into the highest chair in Christendom.

\section{The Counter-Reformation Comes to Florence}

All of Cosimo's successes were very useful, but the same system that opened the church's doors imposed its own limits and boundaries. Those who did favours in Rome expected to receive them in Florence, and one of those favours included bringing the Counter-Reformation to the Arno's banks. This section will use the pontificates of Julius III and Paul IV to show just how linked patronage and CounterReformation could be. Though Cosimo's good standing in Rome during the early 155 os put him in an agreeable mood when the messy and uncomfortable business of auto-da-fé was suggested, by the end of the decade Cosimo was out of credit at the Roman court and had little to lose in the way of patronage. It was then that he showed his independent streak.

It would not be out of place to take a moment to examine Cosimo's own sentiments about heresy and theology. Many students of Cosimo suggest that political expediency alone informed Cosimo's religious policies, assuming, as they do, that 
the duke learned his governance on the pages of Machiavelli..$^{51}$ This line of analysis is probably mistaken; Cosimo may not have been a trained theologian, but not all of his religious opinions were marked by Machiavelli's peculiar brand of apathetic indifference. On the contrary, he had always believed himself safely on the Catholic side of the reformation divide. For instance, when he exhorted a subject to end a vendetta with the argument that the disputant would thereby "gain merit in the sight of the lord," he thereby casually affirmed his attachment to the traditional Catholic doctrine on grace and merit. ${ }^{52}$ And later correspondence reveals this to be no mere slip of the pen; ${ }^{53}$ as a Catholic son, Cosimo apparently made little place in his heart for the Reformation doctrine of sola gratia. Given the man's highly conservative personality, this is no surprise. Cosimo would have looked on the Reformation as a cosa nuova, and all new things stoked Cosimo's suspicions. Indeed, before Rome ever got to him, he was going after heretics on his own. As early as 1544 , he had ordered processions in the city not only for peace, but for the conversion of the Lutherans, ${ }^{54}$ and in 1549, he had to be begged to send a certain heretic named Francesco Puccerrelli to the galleys, as he had apparently personally wanted him burned. ${ }^{55}$ Moreover, it would have been rather a hard case for a Medici, with two popes in the maternal line, to deny the traditional Roman authority. In this case, then, personal belief married nicely to political expediency; his desire to prosecute heresy proceeded at least partially from an uncynical attachment to the traditional religion.

On the other hand, he did not want the apparatus of Roman repression tramping unfettered through his own backyard. Though Cosimo did not always give the inquisition free play, it was no anachronistic concern for religious tolerance that stayed his hand; it was his distaste for the inquisition's methods. He wanted his justice quick; the inquisition was glacially slow. He liked his justice cheap; the inquisition bled its victims dry while holding them interminably in prison. He strove to make his justice impartial; the inquisition proceeded, according to him, far too often on baseless and anonymous whispers uttered by jealous neighbours. ${ }^{56} \mathrm{He}$ did not like it, and he knew his Italian subjects did not like it. Unfortunately, we possess little knowledge of Cosimo's early dealings with the inquisition, courtesy of the mob that sacked the hated institution and burned its documents on the death of Paul IV. The darkness only lifts in the early 1550s, when Cosimo was lending the inquisition the full might of the secular arm. In one single day in 1552, Cosimo's officers arrested 40 heretics, marching them through the streets of Florence to the cathedral, the penitential garb and lit yellow candles testifying to their shame as excommunicants. At the head of the auto-da-fé was one of Cosimo's own, Bartolommeo Panciatichi, ducal secretary. ${ }^{57}$ Panciatichi was not Cosimo's first sacrifice to ecclesiastical policy 
and rigorous justice, nor would he be the last. Cosimo did not even spare his own from the inquisition's dungeons.

Why such deferential treatment to an institution that he so obviously loathed? Simply because his patronage network in Rome wanted it, and he could not hold out against requests from that quarter. Cosimo agreed to the auto-da-fé only after the Master of the Sacred Palace had exhorted him to the brink of tears. The request almost certainly came directly from the pope, ${ }^{58}$ who by this time was none other than his good friend, the former Cardinal del Monte. Cosimo could hardly turn down a pope who had spent the first two years of his papacy showering him with an ample bounty of Roman patronage. Apart from having given Cosimo the stocco and berretone in 1551,59 Del Monte provided secular and ecclesial posts to Cosimo's clients, ${ }^{60}$ giving them considerable favours in their litigation. ${ }^{61}$ Indeed, whereas Cosimo had occasionally refused to write letters to Paul III on the grounds that his recommendations did more harm than good, ${ }^{62}$ now he could send clients back to the eternal city and to a pope who held him in particular esteem. ${ }^{63}$ Even the queen of France asked for Cosimo's intercession since, as Cosimo wrote, "The Most Christian Queen [holds] it as a certainty that my intercession with the Pope can accomplish much." 64 Indeed, Roman patronage had gotten almost too good. Things had reached such a pitch that Cosimo had to remind others that the pope was not a puppet with strings pulled from Florence. As he wrote to his ambassador:

It will do us harm if it seems as if His Holiness moves by our order, because in fact, we do not want to push him but only to remind him and to inform him of everything, so that as a Father and Lord, he might take those expedients that seem suitable. ${ }^{65}$

To a duke who had spent years butting heads against the inimitably thick skull of Paul III, this new concern must have certainly been a welcome problem, even if it meant giving the inquisition more rope than he would have liked.

Indeed, the pope was not the only one in Rome turning the screws on Cosimo. Cosimo's patron Cardinal Carpi was also part of the inquisition's machinery, and if the pope and his Del Monte clan were making demands that Cosimo could not refuse, how much less could he refuse the demands of his relative, the Cardinal Toledo? The Dominican Toledo had sat on the inquisitorial tribunal since its inception in 1542 and appears to have been quietly instrumental in swinging Cosimo to Rome's way of thinking. ${ }^{66}$ The buildup of tensions and threats apparently went on for some time. Already on March 3, 1551, Cosimo had gotten into a spat with one of Toledo's commendatori, and when the dispute had come to the attention of the Cardinal, Cosimo wrote to excuse himself. "I would not have shown so little affection," the still slightly irate duke claimed, "if your comendatori, to whom you 
show so much affection, had not imputed me to be little religious, or to say better, imputed that I was a Lutheran. If he had not done that, I would not have treated him as I did." 77 Stale rumours of his own heterodoxy apparently lingered from his altercations with Paul III, and they were giving Cosimo cause to worry. He was certainly asking himself if that was why Toledo had just failed him in his bid to secure the commenda of San Jacopo sopr'Arno in Florence. ${ }^{68}$ Would Cosimo's most important of relationships and whole patronage network slip through his fingers if he refused to move aggressively against the heretics in his own state? He did not wait to find out. When one of his readers at Pisa came under suspicion later that year, he assured the cardinal that the inquisitors would be given all assistance to prosecute the unfortunate offender.

Because the inquisitor is ordinarily here and hears cases involving similar errors, if anyone accuses him, he can come before them, since the inquisitors are not only permitted by me, but given every aid to be able to castigate whoever errors, and we will do likewise against him, if any heresies are found in him. ${ }^{69}$

However, eventually Cosimo needed to back up his tough talk with a little exemplary justice. Eventually, Cosimo needed to give the inquisition some presence in his own city.

This was the context of Florence's first real auto-da-fé, for it is almost certain that Toledo lent his ascendancy over Cosimo to the Master of the Sacred Palace's exhortations. Tucked obscurely behind Cosimo's other dispatches to the inquisition appears a letter from Cosimo to Cardinal Toledo, sent shortly after the auto-da-fe, which pointed out that the duke had now fulfilled all the promises he had made concerning heresy. ${ }^{70}$ Clearly, Toledo had been twisting the secular arms of his ducal in-law into compliance with the inquisition. Indeed, with Carpi and Toledo badgering him from the inquisition's side and Del Monte hectoring him from the seat of Peter, Cosimo could not hold out for long. The request for harsher inquisition not only came from Rome but from those members of Cosimo's patronage network whom he simply could not refuse.

Cosimo's cooperation during the years of the Del Monte papacy is thrown into relief by his largely indifferent attitude to the blandishments of Paul IV, a far more zealous pope who had gradually choked off Cosimo's access in the papal curia. As Paul moved into ever more intransigent anti-imperial positions, Cosimo's patronage system broke down, and with it the Pope's leverage over Florence. With Toledo dead and more than one imperialist cardinal locked away in Castel San Angelo, Cosimo could hardly expect much patronage from his steadfast supporters in Rome. Nor was the pope personally well disposed to the Hapsburg client-Duke of Florence; 
the vitriolically anti-Spanish Carafa reportedly counseled the duchess Eleonora to begin costuming herself in black since her husband was the son of the devil. ${ }^{11}$ Things had definitely changed. Under the Del Monte pope, clients had flocked to Cosimo's patronage, "having great faith that 'his' intercession could dispose the Pope to do a benefit." ${ }^{2}$ Under Paul, Cosimo apologetically caveated his patronage with the excuse that he did not know, "how well my ink runs in that court in these times."73 And indeed, Cosimo's ink did not run well there. As the English ambassador in Rome noted, the hostile Paul knew just where to squeeze Cosimo to make it hurt, taking out his vengeance against the duke's pro-imperial policies by proceeding, "against many men of (the Pope's) estate who serve the duke of Florence."74 Given such tensions, Cosimo's failures as an intercessor with the bellicose old pope were many. Perhaps Cosimo's most vexing failure was his inability to keep his client Eustachio Petrucci, a Knight of Malta, from losing his commenda. In 1558 Paul ordered all the Knights of Malta to ready themselves for combat as the shadow of the Turkish fleet loomed over the dangerously exposed Christian outpost. Cosimo asked a dispensation for the frail and aging Petrucci, 75 but the duke could neither win permission nor forgiveness; when the elderly knight failed to show, Paul III deprived him of his abbey and turned a deaf ear to Cosimo's attempts to win it back for him..$^{6}$ Paul heard Cosimo's appeals on behalf of the Abbot of Galgano with the same deaf ear, for the duke repeatedly attempted to intercede in order to keep the old abbot from spending his last few days in an inquisition jail. ${ }^{77}$ All efforts were to no avail; Cosimo could offer his clients little more than formal and useless pleas in the Roman courts.

If patronage was the sinew of state, Paul's actions hacked at the very tendons of Medicean Florence itself. On the other hand, with less to lose Cosimo could afford to be less cooperative with Paul's increasingly pitiless campaigns against heresy. Cosimo played the game more deftly this time, asserting independence while avoiding the outright hostility that had ignited passions during Paul III's papacy. For instance, in December of 1557, Cosimo's government firmly rejected the inquisition's creeping tendency to expand their jurisdictional competencies. Processes for scorn of the divine cult, dishonoring sacred things, blaspheming God and the saints, usury, thefts, sacrileges and other wicked things, they argued, had customarily belonged to the state's jurisdiction and would continue to do so. More importantly, the inquisition would have no jurisdiction over Jews. "Florence," the defiant auditor Vinta sardonically remarked, "would not become another Spain, where the inquisition puts its hands on everything." 78 The timing of the pronounce- 
ment was no accident, for Cardinal Toledo had died in September of that same year, and Cosimo could afford a little independence.

With Toledo gone, Cosimo's government continued to draw a line in the sand against Paul's inquisition. When Paul issued an ultra repressive Index of Prohibited Books, Cosimo initially played a waiting game, trying to save the booksellers excessive financial loss by appealing to a stay of execution on some of the less offensive titles. He wrote Torelli:

Having seen what you write to Concino about the commissary of the Inquisition, we will be content that he be able with edicts and other actions to move against the prohibited books that treat of religion and sacred things, or of Magic, spells, geomancy, chiromancy, prophetic Astrology, and similar other matters since we have always been an observer of religion and most fierce persecutor of such crimes, but considering the particular damage to many without any profit from the orders of His Holiness, we want to suspend until we hear from Rome the order for other books, even those by prohibited authors, unless they treat of religion and faith. ${ }^{79}$

Cosimo was almost certainly planning to wait the Pope out, hoping that Paul would simply die before the issue came to a head. However, the obstinate old pontiff refused to comply, showing surprisingly stubborn longevity in his octogenarian twilight. Cosimo still had a trick or two up his sleeve, however, and when Paul pressed him into lighting the bonfires in March of 1559, he indulged in a little sleight of hand, instructing his agents to leave non-heretical titles on the shelves and to make more "show than effect." 80

Even in individual cases, Cosimo dug his heels more firmly into the ground than he had under Julius III. For instance, despite the hostilely indignant requests of the Bishop of Bologna, he refused to extradite the Sozzini heretics, ${ }^{81}$ only sending them after Paul IV was replaced by the friendly Pius IV. ${ }^{82}$ In December of 1558 he promised to send a Tuscan priest named Francesco to Perugia for questioning, but later correspondence suggests that Francesco's extradition never took place. ${ }^{83}$ In January of 1559 he ordered some Spoletini heretics sent to Rome, ${ }^{84}$ but his commissary dallied for so long that they were able to bribe their way out of prison. ${ }^{85}$ And by the middle of 1559 , he was flat out refusing the inquisition's request for extradition. ${ }^{86}$ Indeed, both on the level of grand theory and individual justice, Cosimo's legacy of cooperation with the inquisition became very spotty during Paul's papacy, for Paul gave Cosimo very little motivation to cooperate, and the pope's advanced aged counseled the duke to a policy of Janus-faced quiescence and practical indifference. However, this would not last long. The next two popes were both friends to Cosimo, and both brought the agencies of repression to Florence for good. 
If patronage seems to have dictated Cosimo's attitude toward inquisition, the same patronage ties dictated his attitude to that other great leg of Catholic reform: the Jesuit order. It would be wrong to make a sharp distinction between Jesuits and inquisition since their actions were so mutually intertwined. Indeed, the Roman inquisition had specifically ordered Cosimo's Jesuit confessor to butter the duke up for the inquisitorial crackdown of $1552,{ }^{87}$ and the Jesuits themselves would become the prime persecutors of Sienese heretics during the 1560 s. ${ }^{88}$ Moreover, the same patrons that had foisted the inquisition on Cosimo seem to have slipped the Jesuits into Florence as well. For, despite his personal respect for Diego Lainez, Cosimo could not bring himself to trust fully the new Spanish order. His attitude towards religion was one of nearly unswervable conservatism, and even when he set out to reform an order, he did it with an eye to the past, since to Cosimo, reformation primarily meant reducing observance to "ancient constitutions." ${ }^{89}$ Moreover, the Jesuits had powerful enemies, some of whom were whispering into Cosimo's ears. ${ }^{\circ}$ Thus, Cosimo took his first Jesuits only on the recommendation of Cardinal Carpi, who got the Jesuits a foothold in Florence by making a present of two of them to the ducal couple in $1546 .{ }^{11}$ Always good judges of talent, the Jesuits quickly got the right man on the job, for Diego Lainez soon became the duke and duchesses' personal confessor. In short order, he also won over two of the duke's most influential advisors, Alessandro Strozzi and Giovanni Rossi..$^{2}$ The piously devout duchess seems to have been particularly attached to Lainez, as she repeatedly tried to find ways to keep the pope from sending the talented future general away from Florence. 93 By 1547 , Lainez was giving sermons in the duomo to what he reported as wildly enthusiastic crowds. 94

By this time the Jesuits wanted a place in Florence where they might leverage the court into supporting the order's spiritual work of administering sacraments, converting sinners, and educating talented young nobles. And while the Jesuits may have had powerful enemies, they had powerful friends as well. One of these was Alessandro Strozzi, one of the duke's most trusted advisors on ecclesiastical affairs and a man who knew the ins and outs of ducal politics. When Ignatius asked Strozzi his advice, he quickly pointed out that a letter from Cardinal Toledo might soften the duke's negative attitude toward the order. ${ }^{95}$ When Toledo's letter arrived, it arrived accompanied by the more verbal admonitions of Cosimo's father-in-law, Pedro de Toledo. Lainez reported that when the Cardinal's letter was read at a ducal audience, Cosimo threw up one last defense. In a final gasp of reserve he muttered, "Some of these new things are dangerous, and while there may be some good men in the order, perhaps not all of them are. I've heard stories from Rome that Jesuits 
steal wives from their husbands." Strozzi, Eleanora, and the visiting Pedro de Toledo all then went to work, refuting the rumors and breaking down the duke's obstinate resolve. ${ }^{96}$ Lainez simply looked on in silent satisfaction. Indeed, between Carpi's politic maneuvering and the heavy-handed lobbying of the Toledos, Cosimo could not but be won over. Against the duke's inclination, the Jesuits got their college in Pisa and a subvention from both Eleanora and Cosimo. ${ }^{97} \mathrm{~A}$ few years later, they got the church of San Giovannino in Florence as well. ${ }^{98}$ Like the inquisition, the Jesuits were in Tuscany to stay, bringing with them their educational program, spiritual exercises, and fervent obedience to Rome.

\section{Conclusion}

Cosimo quickly learned that he could not wield ecclesiastical power as an absolutist duke, but he also quickly learned that he could wield it in the time-honoured fashion of patron. Moreover, Tuscans simply expected that the number one citizen would play the part of their protector in Rome. Thus, when there was little to recommend Cosimo to a hostile pope, he appealed to the papal curia. When his subjects had interests that only the curia could satisfy, he turned to the cardinals he could trust. When things ran smoothly, Cosimo grew in legitimacy, power, and reputation; it was a network that he could not afford to ignore. However, nothing in life is free, and the same patronage system that won him so much legitimacy also put him in its own peculiar straitjacket. There was little that he could do. He preferred a friendly pope and hampered range of movement in ecclesiastical affairs to absolute liberty in ecclesiastical affairs and a potent enemy to his south and east. With few exceptions, only when he had nothing to lose in Rome did he show an overweening concern for his own jurisdictional prerogatives. For its part, Rome did not scruple to play on Cosimo's secular interests and press his client network in order to squeeze ecclesiastical concessions out of him. With Jesuits and inquisitors at the gates, Cosimo could do little but huff in annoyance and then meekly let them into the sheepfold. With that, he assured the ascendancy of the Counter-Reformation in Florence.

\section{Notes}

1. For the networks of heterodoxy in Cosimo's Tuscany see Massimo Firpo, Gli Affreschi di Pontormo a San Lorenzo; eresia, politica, e cultura nella Firenze di Cosimo I (Milano: G. Einaudi, 1997). 
2. See Delio Cantimori, Eretici italiani del Cinquecento (1939; Torino: Einaudi, 2002), and Massimo Firpo, Riforma protestante ed eresie nell'Italia del Cinquecento (1993: Roma: Editori Laterza, 2004).

3. See Firpo, Gli Affreschi di Pontormo; John Jeffries Martin, Venice's Hidden Enemies: Italian Heretics in a Renaissance City (Berkeley: University of California Press, 1993); Adriano Prosperi, "L’eresia in città e a corte," in La corte di Ferrara e il suo mecenatismo, 1441-1598 (Copenhagen: Museum Tusculanums Forlag, 1990); Simonetta AdorniBraccesi, Una Città Infetta: La Repubblica di Lucca nella Crisi Religiosa del Cinquecento (Firenze: Leo S. Olschki, 1994); Pasquale Lopez, Inquisizione, stampa, e censura nel Regno di Napoli tra '5oo e '6oo (Napoli: Edizioni del Delfino, 1974), and Valerio Marchetti, Gruppi ereticali Senesi del Cinquecento (Firenze: La Nuova Italia, 1975).

4. Arnaldo D’Addario, Aspetti della Controriforma a Firenze (Rome: Minstero dell'Interno pubblicazioni degli Archivi di Stato, 1972), p. 150.

5. Gustavo Bertoli, "Luterani e anabattisti processati a Firenze in 1552," Archivio Storico Italiano 154 (1996), p. 84. Bertoli argued that Cosimo thought heretical conventicles might become a locus for political dissent.

6. The Florentine senate elected Cosimo in 1537. His initial desire to marry the assassinated Alessandro's widow was both a play for legitimacy and a move to secure his relationship with the Emperor Charles V; for, the widow was Charles's natural daughter.

7. For Cosimo's relationship with Paul III see Michele Lupo Gentile, La Politica di Paolo III nelle sue relazioni colla corte Medicea (Sarzana: Lunense, 1906); Antonietta Amati, “Cosimo I e i frati di San Marco," Archivio Storico Italiano 81 (1923); and Giorgio Spini, Cosimo I e l'indipendenza del principato mediceo (Florence: Valecchi Editore, 1980).

8. Archivio di Stato, Firenze, Mediceo del Principato. Filza 5 carte. 628a-628b (March $28,1546)$.

9. ASF, Med. 197 c. 69 r (April 28, 1552): "e gia stato costa quattro mesi senza haver mai potuto conseguirne il fine, per i molti favori (dice lui) che vengono fatta all'adversario suo familiare del R. Cardinal Trani." All translations are mine.

10. The list is much larger, but for a sampling of cases see ASF, Med. 23 c. 82 (September 30, 1552); ASF, Med. 23 C. 294r-294V (December 10, 1552); ASF, Med. 37 C. 153 r (November 1, 1555); ASF, Med. 183 c. $97 \mathrm{~V}$ (September 13, 1538); ASF, Med. 185 c. 156r (October 23, 1544); ASF, Med. 188 c. 25r-25v (April 30, 1548); ASF, Med. 191 c. 52v (May 22, 1549); ASF, Med. 194 C. 122V (September 26, 1551); ASF, Med. 196 c. 14V (November 13, 1551); ASF, Med. 196 c. 28r (December 2, 1551); ASF, Med. 196 c. 8or-81v (January 24, 1552); ASF, Med. 197 C. 13V (February 27, 1552); ASF, Med. 199 C. 46v (February 17, 1553); ASF, Med. 202 c. 64V (February 20, 1554); ASF, Med. 204 c. 49 r (October 6, 1554); ASF, Med. 207 c. 131 r (August 6, 1558); ASF, Med. 208 c. 35 r (February 27, 1558); ASF, Med. 208 c. 105V-106r (November 14, 1558); ASF, Med. 210 c. 4r (January 5, 1559); ASF, Med. $211 \mathrm{c}$. $42 \mathrm{~V}$ (June 22, 1560).

11. See ASF, Med. 192 C. $92 \mathrm{~V}$ (December 17, 1549); ASF, Med. 195 C. 119v-12or (October 28, 1551); ASF, Med. 196 c. 28v (December 2, 1551); ASF, Med. 196 c. 35 r (December 9, 1551); ASF, Med. 197 C. 29v (March 16, 1552); ASF, Med. 198 c. 119v (September 19, 1552); ASF, 
Med. 199 c. 124 r (May [misdated as June] 5, 1553); ASF, Med. 199 c. 138v (June 4, 1553); ASF, Med. 199 C. 153V-154r (June 30, 1553); ASF, Med. 201 c. 175r (July 1, 1554); ASF, Med. 203 c. 39 r (November 20, 1553); ASF, Med. 206 c. 127v (November 18, 1557); ASF, Med. 208 c. $83 \mathrm{v}$ (September 21, 1558).

12. Baglioni's presence in Cosimo's army is well attested in the secondary literature, as it sparked a violent feud with Paul III when Baglioni put himself at the end of Paul's Perugian rebels. Stefano Colonna was the Luoghotenete Generale of Cosimo's army from 1541 to his death in 1548. See Graham Smith, "Bronzino's Portrait of Stefano Colonna. A Note on its Florentine Provenance,” Zeitschrift für Kunstgeschichte 40 (1977). For notes on GiovanFrancesco da Bagno, see G. B. Adriani, Istorie de'suoi tempi (1583, Prato: Frattelli Giachetti, 1824), vol. 4, p. 65. For Giovan Battista Savelli, see Marucelli, Cronaca Fiorentina, a cura di Enrico Coppi (Firenze: Leo S. Olschki Editore, 2000), p.132.

13. Count Troilo di Rossi of San Secondo had married Bianco Riario Sforza, daughter of Cosimo's paternal grandmother Caterina Sforza. Cosimo was second cousins once removed with the three Cybos: Caterina, Cardinal Innocenzo, and Lorenzo, the Duke of Ferentillo, who had married into the Malaspina family of Massa-Carrara. The Cybos' mother Maria Maddelena dei Medici and Cosimo's maternal grandmother Lucrezia dei Medici, were both daughters of Lorenzo the Magnificent.

14. Riguccio Galluzzi, Istoria del Granducato di Toscana sotto il Governo della Casa Medici a sua Altezza Reale il Serenissimo Pietro Leopoldo: Principe Reale d'Ungheria e di Boemia Arciduca d'Austria, Granduca di Toscana (Milan: Ristampa Anastica, 1974), p. 112.

15. On the first matter, see ASF, Med. 192 c.131r (March 9, 1550). On his supplication to Cardinal Carpi, see ASF, Med. 195 C. 47v (June 25, 1551).

16. See ASF, Med. 202 c. 6v-7r (September 20, 1554).

17. ASF, Med. 197 c. $78 \mathrm{v}$ (April 24, 1552).

18. ASF, Med. 23 c. 66r-67r (September 30, 1552).

19. ASF, Med. 212 c. $99 \mathrm{v}$ (June 3, 1560).

20. To get Cosimo's assistance it helped greatly to have someone on the inside before the murder. Cosimo intervened for Bernardo Camaiani, brother of Cosimo's confidents Piero and Nofri, ASF, Med. 189 c. 75r-75v (November 24, 1548). He also intervened for a criato of his house, Neri da Volterra, ASF, Med. 207 c. 132V (October 21, 1558); for the nephew of Cardinal Poggio, ASF, Med. 23 c. 363 r (December 28, 1552); for a client, Antonio Barzellino (as mentioned in the main text), who had killed his wife when he found her committing adultery, ASF, Med. 197 C. 26v (March 13, 1552); for Conti Alamano, vassal of the pope and creature of the Medici house, AsF Med 23 c. 251r (November 22, 1552); and for an unnamed criato, wanting a dispensation to hold ecclesiastical benefices although he was a convicted murderer. ASF, Med. 210 c. 9 r (January 14, 1559).

21. ASF, Med. 197 c. 26v (March 13, 1552). 
22. ASF, Med. 23 c. 375 r (December 31, 1552); ASF, Med. 196 c. 38rv (December 16, 1551); ASF, Med. 197 C. 25V (March 11, 1552); ASF, Med. 201 c. 13r (September 5, 1553).

23. To cite one example out of many, Cosimo campaigned in order to get benefices that had been left in deposit for the young Alessandro dei Medici, future archbishop of Florence and future Leo XI, before he had come of legal age, notwithstanding the council's prohibition. ASF, Med. 201 c. 110r-110v (April 19, 1554).

24. See for instance ASF, Med. 195 C. 107 r (October 12, 1551).

25. In his early days, Cosimo helped his client and bishop Minerbetti, bishop of Arezzo, resign his bishopric to his relative, ASF, Med. 2 c. 14 r (August 28, 1537). Cosimo intervened to help Cardinal Guidiccioni resign the bishopric of Lucca to his underage relative Alessandro, ASF, Med. 189 c. $57 \mathrm{r}$ (November 7, 1548). He similarly tried to help the archbishop of Siena renounce to a relative, ASF, Med. 212 c. $74 \mathrm{r}$ (May 16, 1560 ).

26. ASF, Med. 188 c. $58 \mathrm{r}-\mathrm{v}$ (May 24, 1548); ASF, Med. 194 c. 5 or-51v (April 10, 1551).

27. For examples see ASF, Med. 23 c. 102 (October o, 1552); ASF, Med. 23 c. 368r (December 30, 1552); ASF, Med. 208 c. 104rv (November 10, 1558); ASF, Med. 4 c. 84r-85v (July, 1540); ASF, Med. 182 c. 158 r (November 26, 1537); ASF, Med. 192 c. 119r (February 26, 1550); ASF, Med. 195 C. 151v (June 5, 1552); ASF, Med. 212 c. 41r (April 28, 1561).

28. These were the biggest favours of all and Cosimo could not assure anything for anybody. Cosimo campaigned unsuccessfully for his client Archbishop Colonna, ASF, Med. 195 C. 106v-107r (October 12, 1551); and for Don Ferrante Gonzaga, ASF, Med. 201 c. $103 \mathrm{rv}$ (April 8, 1554). He successfully secured cardinalships for the Archbishop of Messina, ASF, Med. 195 c. 108v (October 14, 1551); Roberto Nobili, ASF, Med. 202 c. $17 \mathrm{rv}$ (December 26, 1553); his own sons Giovanni (ASF, Med. 212 c. 2 r [February 13, 1560]) and Ferdinand, and his functionary Agnolo Niccolini.

29. Cosimo was instrumental in both Julius III's election (ASF, Med. 323 C. 52r [November 15,1549 ) and Pius IV's. See Furio Diaz, Il granducato di Toscana: I Medici, Storia d'Italia Vol. XI, ed. G. Galasso (Turin: UTET, 1976), p. 186.

30. Konrad Eubel, Wilhelm Gulik, Stefan Ehses, and Patrick Gauchat, Hierachia Catholica, Volume III (Monasterii, sumptibus et typis librariae Regensbergianae, 1898), p. 25.

31. On this matter see ASF Med. 37 c. 331 (December 27, 1555).

32. ASF, Med. 196 c. $13 \mathrm{rv}$ (November 12, 1551).

33. See for instance: ASF, Med. 185 C. 45V (May 5, 1544); ASF, Med. 185 c. 64r (May 14, 1544); ASF, Med. 189 c. 54 r (November 1, 1548); ASF, Med. 192 c. 19 r (October 9, 1549); ASF, Med. 192 C. 131r (March 9, 1550); ASF, Med. 195 C. 65V (July 9, 1551); ASF, Med. 195 c. $106 \mathrm{v}$ (October 12, 1551).

34. ASF, Med. 1170 c. 76 r (December 7, 1552): "non sappai chi meglio li potessi far gratia di benefitii che il cardinale di burgos et don francesco et che lui era duca et li duca non danno benefitii ne entrate ecclesiastiche."

35. See Lorenzo Cantini, ed., Legislazione Toscana Volume One (Albizziana da S. Maria in Campo, 180o), pp. 186-87. 
36. See Eubel, Gulik, Ehses, and Gauchat, pp. 23-24.

37. For instance, it is certain that Carpi held at least on benefice in the diocese of Arezzo. ASF, ABEG. 4375. See also a letter Cosimo sent on behalf of the schalco of Cardinal Carpi's to the commissary of Castrocaro on two vacant benefices. ASF, Med. 182 c. $81 \mathrm{r}$ (August 4, 1537), and ASF, Med. 197 C. 48r (March 31, 1552).

38. ASF, Med. 182 c. $95 \mathrm{~V}$ (September 7, 1537).

39. See ASF, Med. 185 C. 145 V (July 26, 1544); ASF, Med. 323 C. 31 r (May 24, 1549).

40. ASF, Med. 194 C. 115 r-115V (September 14, 1551).

41. AsF, Med. 212 c. 70 (May 15, 1560).

42. For the mutual links of favours that bound the two together, see ASF, Med. 182 c. $81 \mathrm{r}$ (August 4, 1537); ASF, Med. 182 c. 95v (September 7, 1537); ASF, Med. 183 c. 186v (January 25, 1539); ASF, Med. 185 C. $78 \mathrm{v}-79 \mathrm{~V}$ (May 23, 1544); ASF, Med. 185 C. $145 \mathrm{~V}$ (July 26, 1544); ASF, Med. 194 C. 27 r (March 20, 1551); ASF, Med. 194 C. 28v (March 21, 1551); ASF, Med. 195 C. 47v (June 25, 1551); ASF, Med. 212 c. 110r-110v (June 16, 1560); ASF, Med. 323 c. 31 r (May 24, 1549). ASF, Med. 210 c. 48v (April 1, 1559).

43. Averardo Serristori, Legazioni di Averardo Serristori ambasciatore di Cosimo I a Carlo Quinto e in Corte di Roma (1537-1568), compiled and edited by Luigi Serristori (Firenze : Felice le Monnier, 1853), p. 135.

44. Archivio di Stato Firenze, Auditore dei benefici ecclesiastici. 4375 c. 296 (August 6, 1546).

45. ASF, ABE 4375 C. 2 and 63. The same cases make it clear that Cosimo's aid did not extend to subverting justice for Del Monte's gain.

46. This is a plaintive note from Lorenzo Fuggini, whom Cosimo has clearly strongarmed into settling his dispute with Del Monte over Santa Maria di Ambra. ASF, ABE. 4378 c. 324.

47. ASF, Med. 5 c. 633r-634r (April 20, 1546).

48. Julius later made Cosimo's ambassador Bishop of Fiesole. See Hubert Jedin, "La politica conciliare di Cosimo I," Rivista Storica Italiana 62 (1950), p. 364; and Scipione Ammirato, Vescovi di Fiesole, di Volterra, e d'Arezzo del Signore Scipione Ammirato, reprinted from the Florentine Edition of 1637 (Firenze: Arnaldo Forni Editore, 1984), p. 54 .

49. ASF, Med. 10 c. 263 r (July 6, 1547).

50. See footnote 28 .

51. For Cosimo as a sola politica thinker see Firpo, Gli Affreschi di Pontormo, 311; Danilo Marrara, Studi Giuridici sull Toscana Medicea: Contributo alla Storia degli Stati Assoluti in Italia (Milan: Dott. A. Giuffrè Editore, 1965), p. 58; and Eric Cochrane, Florence in the Forgotten Centuries: 1527-180o; A History of Florence and the Florentines in the Age of the Grand Dukes (Chicago: The University of Chicago Press, 1971), p. 60. For Cosimo as Machiavellian see Roberto Cantagalli, Cosimo I: granduca di Toscana (Milan: Mursia editore, 1985), pp. 77-79; Antonio Anzilotti, La costituzione interna dello stato Fiorentino sotto il duca Cosimo I de'Medici (Florence: Francesco Lumachi, 1910), p. 39; and Henk Van Veen, Cosimo I and His Self-Representation in Florentine Art 
and Culture, translated by Andrew McCormick (Cambridge: Cambridge University Press, 2006), pp. 165-66.

52. See ASF, Med. 182 c. 8 ov (August 4, 1537).

53. For similar telling expressions, see ASF, Med. 182 c. 1 (January 15, 1537); ASF, Med. 182 c. 169 r (November 12, 1537); ASF, Med. 182 26v-27r (March 11, 1537); and ASF, Med. 182 46r (May 5, 1537).

54. Cronaca Fiorentina, p. 46.

55. Cronaca Fiorentina, pp. 112-15.

56. An archival quotation might serve best to illustrate his opinion of the inquisition. In 1560 he wrote to the inquisition: "Do not be at all deceived in believing that I am not a most zealous persecutor of Heretics, such is the zeal that I have always had and will always have toward the Holy Catholic Faith and the Holy See. I thank you for the note, that you have given me on the $23^{\text {rd }}$ of the past month, in order to illuminate me about the erroneous opinions spreading in Siena, and of the provisions that you think should be made; but because it would be no marvel, if in a place like Siena, particular passions or ambitions sought to harm others by some sinister invention, I would desire that, as you wrote last week, you come to some particulars about the business; because I will provide in the future against such rebels to the faith of Christ so much that you will not having any difficulty or trouble in knowing what my mind is. Nonetheless, it does not seem that I should have to proceed in the dark in such important business without a good fundament, especially since the business affects mostly honored and noble persons." ASF, Med. 212 c. 118v-119r (June 31 1560). ("Non s'inganano punto le ss.w à credere, ch'io sia acerrimo persecutore delli Heretici, tanto e, il zelo, che ho sempre havuto, et haverò verso la santa fede cattolica et quella santa sede; Ringratiole dell'avviso, che mi danno con la loro di 23 del passto per illuminarmi delle opinioni erronee, che vanno pullulando in Siena, et delle provisioni, che le penserebbeno di farvi; ma perche in simili luoghi non sarebbe maraviglia, che le passione particolari; o', qualche ambitione cercassero per nuocere altrui far di sinistre inventione, desidererei si come scrissi alle settimane passate, che le ss.w.r. discendesser meco à quel che particolare, perche oltre al conoscere qual sia la mente mia contra simili rebelli della fede di Cristo, provederei per avventura di tal remedio, che le non haverebbino in ciò fatica, nè molestia alcuna; nondimeno l'havere à, procedere al buio in cosa tanto importante non mi pare, che si debba fregiar persona massime nobile, et honorata senza buon fondamento.")

57. The most detailed secondary work on Cosimo's auto-da-fé is Bertoli.

58. It seems that the Pope personally assured the Venetian ambassador of Cosimo's commitment. See Bertoli, p. 64.

59. Firpo, Gli Affreschi di Pontormo, p. 379.

6o. Cosimo, for instance, won Piero Guicciardini a spot as a collaterale of the Campodoglio, a civic judgeship in Rome. For the request, see ASF, Med. 194 c. 35v (March $28,1551)$. The thank you note for the successful bid is in ASF, Med. 196 c. 79 r. Cosimo also got his client the Bishop of Pavia the governorship of Rome. ASF, Med. 196 c. $28 \mathrm{r}$ 
(February 12, 1551). For other successes see ASF, Med. 199 c. 138v (June 4, 1553); and ASF, Med. 199 c. 153V-154r (June 3, 1553).

61. ASF, Med. 194 C. 19 r (June 23, 1551); ASF, Med. 194 c. 36r (March 28, 1551); ASF, Med. 194 c. 114V (September 14, 1551); and ASF, Med.196 c. 24V (November 30, 1551). For his part, Cosimo had granted Del Monte San Sovino outright as a fief to the pope's brother Baldovino.

62. ASF, Med. 5 C. 511r-511v (March 25, 1544).

63. ASF, Med. 192 C. 136v (March 11, 1550).

64. Archivio Segreto Vaticano, Segr. Stato, Principi 17 c. 115 (October 13, 1552): "La christianissima Regina tenendo per fermo che la intercessioni mia appresso V.Sta habbia à poter molto."

65. ASF, Med. 323 c. 10or-101r (Maggio 1551): "ci faria danno il vedersi che SS.ta la stringessi per nostro ordine perche in fatto non vogliamo stringerla ma solo ricordar e informare Ssta del tucto accio da padre e signore, pigli quelli expedienti li parranno a proposito."

66. Eubel, Gulik, Ehses, and Gauchat, p. 25.

67. ASF, Med. 194, 8r (March 3, 1551): "Se il Commendator Rengisso (al quale la S.V. ILL. et $\mathrm{R}$ mostra particulare affectione), non m'havesse imputato per poco religioso, o per dir meglio, per Lutherano, non harei fatto il resentimento che ho fatto con esso lui."

68. This, at least, is what he implied to Burgos in the same correspondence.

69. ASF, Med. 195 C. $79 \mathrm{~V}$ (July 21, 1551): "perche qui dove ordinariamente é lo inquistori si riconoscano simili errori se alcuno lo accusa può venire da esso, che sendoli non sol permessa da me, ma dato ogni favore, per potere castigar chi erra, si farà il simile contra di lui, se si troverà che in lui sieno heresie."

70. AsF, Med. 196 c. 93V-94r (February 9, 1552).

71. Cited in Cecily Booth, Cosimo I, Duke of Florence (Cambridge: Cambridge University Press, 1921), p.160.

72. ASF, Med. 201 c. 103r-103v (April 8, 1554): "haver gran fede che la intercessione nostra gli habbia molto à giovare in disporre S.S. à farlo questo benefito.”

73. ASF, Med. 37 c. $157 \mathrm{r}$ (November 2, 1555): "io non sappi, come à questi tempi corra il mio inchiostro à quella corte."

74. From: "Mary: January 1556," Calendar of State Papers Foreign, Mary: 1553-1558 (1861), pp. 201-206. URL: <https://www.british-history.ac.uk/report.aspx?compid=70428>. Date accessed: 13 September 2008. It was for instance in 1555 that Paul IV deprived the duke's soldier GiovanFrancesco da Bagno of his castle. See Adriani, vol. 5, pp. 99100.

75. ASF, Med. 208 c. 126r-126v (December 18, 1558).

76. And Cosimo was still asking in 1560. See ASF, Med. 212 c.10ov (June 3, 1560).

77. ASF, Med. 208 c. $68 \mathrm{v}$ (August 28, 1558).

78. Anzilotti, p. 190-91.

79. ASF, Med. 210 c. 2 or (February 13, 1559): "Veduto quanto scrivete al concino circa il commissario dell'Inquisitione, ci contentiamo che egli possa con editti, et altro 
esseguire contra li libri prohibiti, che trattano della religione, et cose sacre, ò di Magia, incanti, geomantia, chiromantia, Astrologia giudicaria, et simile altre materie, sendo noi stati sempre osservanti della religione, et persecutore acerrimo di cotali delinquenti, ma considerando al danno poi di molti particolari senza profitto alcuno delle ordinationi di S.S. vogliamo che si sospenda, sino á nuovo precetto di Roma, la esecutione delli altri libri, etiam de medesimi Auctori prohibiti, purche non trattino di religione ò fede."

80. ASF, Med. 210 c. 33V (March 11, 1559): "si facesse piu dimostratione che effetti."

81. Marchetti, p. 165; and ASF, Med. 210, 65r (April 20, 1559).

82. Marchetti, p. 232.

83. For the promise to extradite to Cardinal Alessandrino, see ASF, Med. 208 c. 134r (December 24, 1558). For the order for his immediate release, see ASF, Med. 210 c. $20 \mathrm{~V}$ (February 14, 1559).

84. ASF, Med. 210 c. 11 (January 21, 1559).

85. ASF, Med. 210 c. $44 \mathrm{~V}$ (March 30, 1559).

86. ASF, Med. 207 c. 138v (June 2, 1559).

87. Juan Polanco, Epistolae et commentaria P. Joannis Alphonsi de Polanco e Societate Jesu; addenda caeteris ejusdem scriptis dispersis in his monumentis, quibus accedunt nonnulla coaeva, aliorum auctorum, illis conjunctissima (Rome: Monumenta Historica, 1961), vol. 1, p. 34 .

88. See Marchetti, pp.162-164, and 196.

89. ASF, Med. 183 C. $198 \mathrm{r}$ (February 22, 1539).

90. Ignatius of Loyola, Monumenta Ignatiana, ex autographis vel ex antiquioribus exemplis collecta. Series prima. Sancti Ignatii de Loyola Societatis Jesu fundatoris epistolae et instructiones (Matriti: Typis G. Lopez del Horno, 1903-1911), pp. 458-59.

91. Galluzzi, p. 366.

92. Galluzzi, p. 366.

93. Polanco, vol. 2, p. 179.

94. Diego Lainez, Lainii monumenta; epistolae et acta patris Jacobi Lainii, secundi praepositi generalis Societatis Jesu (Matriti: Typis G. Lopez del Horno, 1912), vol.1, pp. 63-64.

95. Epistolae mixtae, ex variis Europae locis ab anno 1537 ad 1556 scriptae Monumenta Historica Societatis Iesu (Matriti, excudebat A. Avrial, 1898-1901), vol. 1, pp. 336-37.

96. Ignatius, p. 717: "Su Excelencia tocó otro capítulo, diciendo que estas cosas nuevas son peligrosas, y que aun cuando algunos sean buenos en la Compañia, no lo son todos. Y habló de ciertas ocurrencias de Pistoya y de otras cosas que Marcos Bracci le había dicho de Roma, es á saber, nosotros quitábamos las mujeres á sus maridos.”

97. Polanco, vol. 2, p. 41.

98. Polanco, vol. 3, p. 213. 